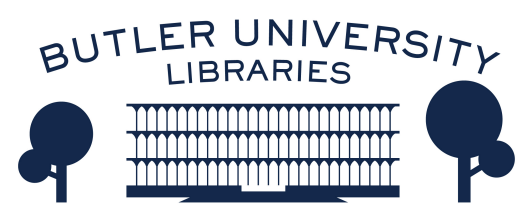

Journal of Hindu-Christian Studies

January 2009

\title{
Book Review: "Kurisumala: Francis Mahieu Acharya--A Pioneer of Christian Monasticism in India"
}

\author{
Edward T. Ulrich
}

Follow this and additional works at: https://digitalcommons.butler.edu/jhcs

Part of the Religion Commons

\section{Recommended Citation}

Ulrich, Edward T. (2009) "Book Review: "Kurisumala: Francis Mahieu Acharya--A Pioneer of Christian Monasticism in India"," Journal of Hindu-Christian Studies: Vol. 22, Article 20.

Available at: https://doi.org/10.7825/2164-6279.1447

The Journal of Hindu-Christian Studies is a publication of the Society for Hindu-Christian Studies. The digital version is made available by Digital Commons @ Butler University. For questions about the Journal or the Society, please contact cbauman@butler.edu. For more information about Digital Commons @ Butler University, please contact digitalscholarship@butler.edu. 
The similarities between Yajña and the Eucharist become obvious in the Vedic five great daily sacrifices. (pañca-mahāyajña). Praseed is at his comparative best in Chapter Seven of the book where he holds sacrifice to the gods (devayajña) alongside the Eucharist as sacrifice to God the Father; sacrifice to the dead (pitryajña) alongside the offering of the Eucharist for the dead; sacrifice to all living beings (bhütayajña) alongside the intercession for the well-being of all in the Eucharist; sacrifice to human beings (nryajña) alongside the Eucharist as the agapic meal; and sacrifice to
Brahman (brahmayajña) alongside the liturgy of the Word.

Originally written as a doctoral dissertation presented to the Institute of Pastoral Liturgy, Abbey of St. Justine, Padua (under the author's old name George Padinjattukara Varkey), the book is both insightful and informative even if somewhat wordy and repetitive. Praseed quotes profusely from theologians past and present, and provides a useful glossary and a bibliography.

Swami Tyagananda

Harvard University

\section{Kurisumala: Francis Mahieu Acharya-A Pioneer of Christian Monasticism in India. Marthe Mahieu-De Praetere. Trans. by Susan Van Winkle. Kalamazoo, Mich.: Cistercian Publications, 2007, xv + 394 pp.}

WESTERN scholars of the contemporary Hindu-Christian encounter are familiar with the towering figures, Swami Abhishiktananda and Bede Griffiths, and with their institution, Shantivanam Ashram. Much less is commonly known among scholars about their one-time confrere, Francis Acharya (1912-2002). Acharya and Griffiths had together founded Kurisumala Ashram, an institution that is strong and thriving today, so it is surprising that Acharya is not better known. However, this situation may soon change, for Acharya's niece, Marthe Mahieu-De Praetere, has written the first biography of him. It was first published in Belgium in 2001 and an English translation was published in 2008.

Francis Acharya was born as Jean Mahieu to a wealthy, Catholic family in Ypres. The young Mahieu could have had a very successful career in his father's Union Factory, but he had a life changing experience in 1931 while he was a student in England. He caught sight of Gandhi on the latter's famous visit to London and was impressed by the man's display of simplicity before the pomp of the British Empire. He stated, "For me, it was the victory of a man who incarnated poverty. It was the epiphany of a purely spiritual power and I dreamt of following the same path" (22). Mahieu dismayed his father four years later by entering the monastery of Our Lady of Scourmont in Chimay, where he followed a very ascetical lifestyle. In the coming decades he nurtured an interest in Indian spirituality and gained permission in 1955 from his superiors to move to India. There he joined Jules Monchanin and Swami Abhishiktananda at Shantivanam Ashram, which had been established four years earlier. Mahieu was fascinated by their project of integrating Christian monasticism with Indian culture.

Acharya's interests quickly moved away from Shantivanam. Soon after his arrival in India in 1955 he met Raimundo Panikkar, who introduced him to Bishop René Feuga of Mysore. The bishop, in turn, introduced Acharya to some of the thriving Christian communities of Kerala. Acharya was deeply enchanted by the vibrant community life and the Syriac liturgies he encountered, versions of which had been celebrated in India since the earliest eras of church history (139-42). Acharya had a great love of the early Christian theologians of the East, and the Syriac liturgy was a living link to that world $(82,98)$. Further, he was disappointed that Shantivanam was failing to attract new members and to build a strong community life. Acharya hence resolved to found a monastery in 
Kerala which would focus on the Syriac liturgy and which would draw on the local Christian communities for membership $(136,141-42)$. He pooled efforts with Bede Griffiths and two Indians, Sylvester and Vargheese, and founded Kurisumala Ashram in 1958 near Vagaman in the Western Ghats (162-63). ${ }^{1}$ Acharya and his community successfully struggled to develop a monastery, farm, and thriving community in an area that had originally been very sparse and technologically undeveloped.

Kurisumala Ashram focuses on HinduChristian dialogue in several ways. To begin, like Shantivanam, it meshes many customs and practices of Hindu monasticism with the Benedictine monasticism of the Christian West. Further, it extends hospitality to Hindus. For instance, a "Swami Dharmananda" lived there from 1969 until settling in the Himalayas in 1976 , and it maintains good relations with the Ramakrishna Ashram in Pala (264). In addition, the monastery has long had daily sessions of satsang, in which Hindu and Christian texts may be alternatively read in a prayerful manner. Also, in 1972 the Ashram adopted for daily use the Bharatiya Puja or Indian Rite Mass which had been developed earlier in Bangalore (26163). However, Acharya's most distinctive scholarly contribution, which has received much acclaim from scholars, was a translation of the Penqitho, which contains the daily monastic prayers of the Syriac Antiochene Rite. He adapted the Penqitho for daily use at Kurisumala, publishing it as Prayer with the Harp of the Spirit and interspersing select Hindu prayers among the Christian prayers. ${ }^{3}$

Given that Kurisumala Ashram is flourishing today, and that many in the Syrian churches of Kerala are very proud of it, it is surprising that the institution is not better known among Western scholars of Hindu-Christian dialogue. The reason might be that some of Acharya's main achievements, such as translating the Penqitho and establishing its usage at Kurisumala, were contributions operating mainly within the domain of Christian spirituality. In contrast, Bede Griffiths and Swami Abhishiktananda were more directly involved with Hindu spirituality and wrote extensively about the issues that arise when Advaita and Christian faith encounter each other. Further, much of the Hindu-Christian encounter at Kurisumala is on the level of prayer and contemplation, rather than on the levels of theoretical formulations and historical happenings, both of which can more easily be written about. Still, the lives of Jules Monchanin, Swami Abhishiktananda, Raimundo Panikkar, Bede Griffiths, and Francis'Acharya are intertwined, and the latter deserves far more study and attention by scholars.

Mahieu-De Praetere's biography is the first book to widely disseminate information about Acharya's life, and it gives a wealth of valuable information. However, it is problematic in scholarly terms. To begin, verifiable historical facts are meshed together with a narrative or story-telling style, making the reader wonder about fact and conjecture. For instance, the book gives lengthy verbatim conversations, some going back to the 1930 s, with no citations. Also, large amounts of other information are given with minimal citation, making the reader wonder about fact and conjecture. The author states that she relied on a wide variety of documents, correspondence, and interviews and that Acharya "checked the text word by word" (ix). This book has many flaws, but if it promotes further. research it will have played a valuable role.

\section{Notes \\ ${ }^{1}$ Griffiths had arrived in India in 1955 and would depart Kurisumala in 1968 to take charge of Shantivanam, after Abhishiktananda's departure from there to settle in the Himalayas. \\ 2 Swami Vamadevananda of the Ramakrishna Mission formally received Acharya's biography at a celebration of its release at Anugraha Renewal Center in Kottayam in 2008. \\ ${ }^{3}$ See, for instance, Robert Taft, The Liturgy of the Hours in East and West: The Origins of the Divine Office and Its Meaning for Today (Collegeville: Liturgical Press, 1986), 246.}

Edward T. Ulrich

University of St. Thomas 